\title{
The labour market position of narrow versus broad vocational education programmes
}

\author{
Johan Coenen ${ }^{1}$, Hans Heijke ${ }^{2^{*}}$ and Christoph Meng ${ }^{3}$
}

\author{
*Correspondence: \\ h.heijke@ \\ maastrichtuniversity.nl \\ ${ }^{2}$ Department of Economics \\ and Research Centre \\ for Education and the Labour \\ Market, Maastricht University, \\ P.O. Box 616, 6200 Maastricht, \\ MD, Netherlands \\ Full list of author information \\ is available at the end of the \\ article
}

\begin{abstract}
This paper compares narrow, or specialised, and broad, or less specialised, upper-secondary vocational education (VE) programmes in the Netherlands with respect to their graduates' position in the labour market. The data are from three cohorts of the Dutch VE Monitor, a survey of VE graduates 18 months after graduation. The programmes of the highest level_Level 4-of the school-based learning route are investigated. To separate narrow from broad programmes, a novel criterion is used, based on the argument that the match between education and a job within a narrow programme's occupational domain is better than outside that domain and that, for a broad programme, such a match does not differ significantly between the programme's domain and outside it. This study shows that graduates from narrow education programmes have a less favourable labour market position than graduates from broad programmes. They have a greater chance of being unemployed and are more often mismatched in their jobs, both horizontally and vertically. They earn less in any case, particularly if their job is outside their occupational domain or below their level. They consequently experience worse career opportunities and many are more dissatisfied with their jobs. To solve this problem, it would be better to focus on realising a shift in the influx of students from narrow to broad education programmes instead of broadening all narrow programmes. Besides this shift to broader programmes, offering broad variants of narrow programmes while maintaining the narrow, specialist variants could be highly allocation efficient.
\end{abstract}

Keywords: Vocational programme, Programme broadness, Labour market position JEL Classification: 121, J24

\section{Background}

A properly functioning economy requires the deployment of a wide variety of occupational skills. If the supply side of the labour market consisted exclusively of school leavers with a general education, employers would face the costly task of teaching all lacking occupational skills themselves. The Netherlands, however, has an extensive vocational education (VE) system, covering both the secondary and tertiary education levels.

\section{Springer}

(c) 2015 Coenen et al. This article is distributed under the terms of the Creative Commons Attribution 4.0 International License (http://creativecommons.org/licenses/by/4.0/), which permits unrestricted use, distribution, and reproduction in any medium, provided you give appropriate credit to the original author(s) and the source, provide a link to the Creative Commons license, and indicate if changes were made. 
Therefore, almost half ( $45 \%$ ) of the population has completed a full-fledged VE. ${ }^{1}$ This does not automatically mean, however, that this portion of the population is optimally prepared for their occupations after leaving school. After all, the diversity of the content and the levels of the education programmes completed must match a wide range of occupations, both qualitatively and quantitatively, that must be filled for the economy to function efficiently.

A good match implies that, having left school, a graduate needs to invest relatively little to acquire missing knowledge and skills to function properly in the occupation obtained. Ideally, the available VE programmes should produce graduates who achieve a high level of productivity while they work in the occupations for which they were educated. It is impossible, however, to match exactly the supply of education programmes to future employment in the occupations for which students are trained and the future changes in the content of these occupations, as well as the specific choices future students will make, given the programmes offered. Not long after graduation, on average, a quarter of all graduates obtain work outside the occupational domain of their study programme (Research Centre for Education and the Labour Market 2010). ${ }^{2}$ An important question is, therefore, how to align VE with the volatile demands of the labour market and the educational choices to be made. The use of sound labour market forecasts and information on education programmes that also concentrates on the labour market perspectives of the programmes offered will not be sufficient. In addition, VE should be set up to ensure minimal adaptation costs if changing labour market circumstances force workers to resort to occupations that are further removed from the specific occupations for which they were trained. Workers should also be trained so that they will adapt relatively easily to future changes in the content of their occupations that their VE cannot anticipate.

In the Netherlands, it has been argued for a long time that the adaptive power of secondary VE should be increased, particularly by broadening the education programmes offered (Van Hoof and Dronkers 1980). ${ }^{3}$ This paper contributes to the discussion on the desirability of broadening education programmes by empirically analysing the differences in the labour market positions of graduates from narrow education programmes, who specialise in particular (domains of) occupations, and graduates from broad education programmes, whose acquired skills can also be used well outside their programmes' specific occupational domains. An essential question in this context is whether the position of graduates from narrow programmes is indeed more vulnerable than the position of graduates from broader programmes.

The implications of the narrow or broad deployability of skills acquired in occupational training are amply discussed in the literature. Many studies focus on the question why firms offer or subsidise apprenticeship training, given the transferability of acquired skills to other firms (Becker 1962; Franz and Soskice 1995; Acemoglu and Pischke 1998;

\footnotetext{
1 This figure was obtained from Statistics Netherlands (2011). It concerns the population with an education from uppersecondary Level 4 VE to university education as a percentage of the population aged 15-65 years. University education is considered vocational education in this paper, albeit with a distinct academic component.

2 We define the occupational domain of an education programme as the occupations for which the programme concerned or a related programme is required. We mostly use the term occupational domain instead of occupation to convey that graduates of one education programme can end up in different, more or less related occupations.

3 For a more balanced assessment, see Borghans and De Grip (1999).
} 
Euwals and Winkelmann 2001). The transferability of skills may be limited because of their firm-specific nature, but also because of asymmetrical information and other market imperfections or their industry-specific character (e.g. Katz and Ziderman 1990; Stevens 1994; Smits 2005). In the case of apprenticeship training, however, the share of firm-specific skills is probably small (Mueller and Schweri 2012; Pfeifer et al. 2011). Industry- or occupation-specific skills, on the other hand, appear more important, considering the significantly lower mobility to positions outside the industry or occupation (Geel et al. 2011) and the significant wage loss from switching industries (Carrington 1993; Neil 1995; Weinberg 2001) or occupations (Geel and Backes-Gellner 2011; Mueller and Schweri 2012). Geel et al. (2011) conclude that apprenticeship training becoming less occupation specific could lead to greater occupational mobility. The questions are, however, whether this broadening of the education programme improves the labour market position of those involved and how this relates to the potential deterioration of the position of those who find work in the occupation or group of occupations within the programme's occupational domain. We therefore examine the chances of finding a job and the material and immaterial earnings of graduates from narrow versus broad education programmes in both the programme's occupational domain and, when forced by labour market circumstances, outside it.

As Heijke and Borghans (1998) point out, broadening VE programmes has both advantages and disadvantages. The broader, or less specialised, the programme, the easier the adaptation to both occupational requirements outside the programme's specific occupational domain and future innovations within the domain itself. A narrow programme, however, provides a high degree of specialisation in a particular discipline or specific occupation. Graduates who obtain a job in such an occupation shortly after graduation will perform better than other graduates with a broader education. If there is insufficient work in this specific occupation, they will need to resort to a different one. There, they are not likely to perform as well and will find it more difficult to adapt than those with broader training who find work in this occupation. In broadening an education programme, the lower costs of adaptation to different occupational requirements are offset by lower performance in a specialist occupation. The question of broad versus narrow education programmes therefore involves an economic trade-off between these two implications of the programme for future labour market positions.

According to this line of reasoning, productivity and wages depend on the degree of alignment between the skills acquired in education and training and the skills required in the available occupations in the labour market (Tinbergen 1956; Jovanovic 1979; Hartog 1992; Geel and Backes-Gellner 2011). In addition, whether the allocation of labour across occupations is within or outside one's occupational domain or at the education programme's proper level is controlled by the comparative advantage that education programmes provide in the performance of tasks in these occupations (Sattinger 1975, 1993). This comparative advantage is partly determined by the transferability of acquired skills to other professions. Partly due to market failure, the labour market performance is not perfect. We therefore look at not only wages and horizontal and vertical (mis)match, but also the chances of not finding a job and, therefore, of being unemployed and having to search longer before the first job is found. In addition, we look at job satisfaction and perceived career perspectives. 
We focus on educational programmes at the highest level within upper-secondary VE, that is, middle management and specialist training. For this, we use the VE Monitor, ${ }^{4}$ an annual survey of the labour market positions of VE graduates about 18 months after graduation. Consequently, the data from the survey concern the transition stage from school to work.

Dutch upper-secondary VE distinguishes two learning routes, both of which combine school education and practical training and result in formally equivalent diplomas. In the work-based learning route (the former apprenticeship system), which is taken by almost a third of the students, the practical component dominates, whereas in the school-based learning route the school component does. ${ }^{5}$ These routes may therefore attract different types of students: those with an affinity for learning in practice and those who prefer a school-based approach. Furthermore, schools - in programmes that follow the work-based learning route-may use the discretionary room that they have within formal curriculum demands not to broaden the programme's labour market perspective but, rather, to create a better match with a specific part of the regional business community. This would give these education programmes a narrower scope in the labour market. Education programmes offered through the work-based learning route not only are a priori narrower, but probably also exhibit less variation in broadness between programmes than programmes with a school-based learning route. The larger practical component in the work-based learning route and closer ties with companies involved in this part of the programme with which students have often already signed an employment contract could imply that this learning route offers a greater chance of finding a job after programme completion. In addition, given the unobserved heterogeneity of the two student populations, there are differences in labour market opportunities between the two programme variants that are unrelated to the broadness of the programme but which appear to be statistically associated if no distinction is made between the learning routes. We therefore focus solely on programmes with the school-based learning route.

Our main findings indicate that graduates from narrow education programmes have a less favourable labour market position than graduates from broad programmes. They have a greater chance of being unemployed and are more often forced to resort to jobs outside their programme's occupational domain and below the education programme's level. They also earn less, particularly if their job is outside their domain and below their level. They consequently experience worse career opportunities and many of them are more dissatisfied with their jobs.

The paper is organised as follows. The next section shapes a theoretical framework by presenting in greater detail theoretical considerations and expectations about the labour market position of graduates from narrow and broad education programmes. The "Data" section discusses the data set used in the empirical analyses. An overview and discussion of some of the descriptive statistics of the various education programmes are provided as well. The section "Demarcation of narrow and broad education programmes" discusses and develops a standard to distinguish between broad and narrow

\footnotetext{
${ }^{4}$ The MBO (Middelbaar Beroeps Onderwijs) Monitor, in Dutch.

5 The practical experience component of the work-based learning route consists of three to 4 days a week, but only one to two days a week for the school-based learning route.
} 
education programmes. The section "Labour market position of narrow versus broad education programmes" analyses the differences between narrow and broad education programmes with regard to the labour market position of their graduates. The final section concludes the paper.

\section{Theoretical considerations and expectations}

\section{Function and regularisation of VE}

From a purely labour market perspective, VE programmes should ideally be set up so that graduates achieve high productivity rates in their occupations during their working lives. In addition, the costs of adaptation should be minimal during the transition from school to work, when switching to a different occupation, and when occupational requirements change later in one's career. However, VE has a broader task than merely promoting an efficiently operating labour market. The law that regulates upper-secondary VE in the Netherlands states that this type of education should be aimed at providing theoretical and practical preparation for occupations for which a qualifying education is required or may be useful. ${ }^{6}$ In addition, VE is expected to promote the general education and personal development of students and to contribute to their social functioning. These two tasks of VE need not conflict and could even be extensions of each other. Expanding on this issue, however, is beyond the scope of this paper.

We now focus on the broadness of VE programmes. It is important to note that the first task specified by the law, by virtue of its focus on preparation for certain occupations, demarcates to some extent the broadness of VE programmes. The knowledge and skills taught in a VE programme focus primarily on the requirements for properly functioning in the specific occupations for which it intends to prepare its students. The second task concerns certain generic aspects, such as general education, which provide the broadness of a programme. Nevertheless, the setup of the occupational preparation portion of the programme may also contribute to its broadness. Concentrating on teaching basic knowledge in various disciplines will provide graduates with greater flexibility in the labour market. The information technology (IT) knowledge acquired for occupations in the graphics industry, for example, could be applicable in other, more specific IT occupations. Similarly, basic biological knowledge in agricultural occupations may also be useful in horticultural occupations.

Decision making in the provision of publicly funded VE programmes is highly regulated. Schools can offer only education programmes whose final attainment levels are listed in the central VE programme register (CREBO). The final attainment levels can be described as the competencies in knowledge, insight, skills, and possibly occupational attitudes that graduates need to function properly in their occupations or which are important for further education. These final attainment levels were drawn up by industry-specific knowledge institutes that are closely allied to the organised business community. ${ }^{7}$ This is to ensure that the education programmes have labour market relevance. When the official regulation was evaluated, it was pointed out, by Borghans and Heijke (2004) in particular, that there was a risk that this link could be an obstacle to the

\footnotetext{
${ }^{6}$ Dutch Law on education and vocational education (Wet educatie en beroepsonderwijs, WEB), Article 1.2.1.

7 Strictly speaking, the institutes submit a proposal to the Minister of Education, who then formally determines the final attainment levels.
} 
creation of an adequate supply of education programmes that provide broad and lasting qualifications for occupational life. The strong link between the knowledge institutes and (the interests of) a particular industry could easily result in too much differentiation between education programmes, with insufficient attention to their long-term aspects. The main fears in this respect concern industry-transcending developments and new developments in the labour market, the teaching of broadly applicable core competencies, as well as the personal development and social functioning of students. Schools have some leeway in determining part of their course material. This enables them to adapt to the regional supply of students and/or the demands of the regional business community. It is important that schools focus on the preferences of students to ensure high course participation rates. This guarantees a high level of government funding for the schools. It is also important for schools to consider the preferences of the business community when deciding on the courses to offer. Businesses must be prepared to provide traineeships for students to acquire practical experience or to employ graduates, starting their occupational careers. If the supply of courses does not adequately match the demands and possibilities of the business community, the school's reputation could be harmed.

A narrow education programme can be highly motivating for students, because it enables them to form a clear image of what their desired occupation entails. A broad education programme, on the other hand, can be highly motivating for students who look at the long term or who are unsure of the occupation they want to choose. For them, the education programme has a certain option value (Dothan and Williams 1981; Heijke and Borghans 1998). Students will want to consider the possibility, after graduation, of having to accept jobs outside their education programme's specific occupational domain and that the content of the occupation may change over time. If schools focus primarily on students' short-term motives, the education programmes offered will become narrower.

If schools want to ensure that their courses match the business community's demands, similar considerations play a role. Businesses and institutes offering jobs to graduates from VE programmes may do so primarily to serve their short-term interests. Such organisations want students who wish to gain practical experience during their studies and graduates who want to be employed in regular jobs for immediate involvement in the production process. In that case, organisations will be less inclined to consider the long-term interests of their young employees as a smooth adaptation to later changes in their careers. They will also be less concerned about whether these employees will be able to adapt properly to new ways of doing their jobs. If schools also allow themselves to be guided by short-term motives with regard to the preferences of the business community, the education programmes offered will be narrowed.

Room for broadening VE programmes is limited if one wishes to maintain sufficient depth of the various topics to be taught. Apart from the room provided by the CREBO requirements, there are limits to the duration of the courses and levels of students. The way this broadening is implemented is also important. Broadening in a subject-specific 
sense has completely different implications for the setup of the education programme than concentrating on the acquisition of generic skills. ${ }^{8}$ We elaborate on both options. ${ }^{9}$

\section{Acquisition of subject-specific and general skills}

The subject-specific knowledge and skills taught in a VE programme focus on the ability to function properly in a particular occupational domain. If the subject-specific knowledge concerns the basic knowledge for an occupation, its applicability extends to related occupational domains. For example, if the knowledge of wood that a carpenter needs also provides insight into a variety of other wood characteristics, this knowledge can be applied in other occupations in the wood trade. If the curriculum concentrates on wood conservation options, the knowledge can be applied to the painting trade. If there is a greater concentration on automation in woodworking along with basic aspects of IT, then the knowledge can also be applied outside carpentry. Generally, if subject-specific knowledge is required in multiple jobs, the education programme tends to be broader. In addition to subject-specific knowledge and skills, VE programmes also teach general knowledge and skills. Apart from the general knowledge required to function in society, this could also include the ability to function in work situations, effective cooperation with colleagues, adequate oral communication skills, and the ability to quickly acquire new knowledge and skills. These types of knowledge and skills are required in almost all types of occupations. Generally, therefore, the more the education programme concentrates on teaching these kinds of general skills, the broader the programme's perspective vis-à-vis the labour market. ${ }^{10}$

\section{Theoretical assumptions and expectations relating to labour market position}

To contribute to the discussion of narrow versus broad programmes in VE, we analyse the labour market positions of graduates from narrow education programmes compared to those from broad ones. The idea that education is an investment that has economic returns, particularly in the labour market, has been proposed prominently through Becker's (1962) human capital model. VE is differentiated on the basis of education programmes that prepare for different occupations. The returns of the human capital generated in the various programmes are not the same for every occupation. According to job matching or assignment models, the characteristics of the job or the occupation also play a role. Productivity and matching wages are determined by the skills acquired in the education programme compared to the skills required in the occupation (Tinbergen 1956; Jovanovic 1979; Hartog 1992; Geel and Backes-Gellner 2011). The graduates' productivity is therefore highest when they end up in jobs within their programme's occupational domain. In jobs outside this domain, their productivity depends on the transferability of acquired skills to the domain concerned. Education programmes therefore provide their graduates with a comparative advantage when they perform in jobs within the programme's occupational domain. The comparative advantages control the allocation of graduates across available jobs (Sattinger 1975, 1993; Teulings 1995; Van

\footnotetext{
${ }^{8}$ For a more detailed discussion of this matter, see Nijhof (1998) and Borghans and De Grip (1999).

${ }^{9}$ For a theoretical analysis of the costs and returns of VE programmes in relation to their broadness, see Heijke and Borghans (1998).

10 The statements about subject-specific and general skills are from our contribution to Research Centre for Education and the Labour Market (2007, Section 4).
} 
Eijs and Heijke 2000; Dupuy 2004). Depending on supply and demand in the labour market, some graduates may end up in jobs outside their programme's occupational domain. In the case of optimal allocation, however, they cannot increase productivity by changing jobs anymore. In practice, supply and demand exhibit unpredictable dynamics and market imperfections result from asymmetrical information between graduates and employers and due to such institutions as minimum wage and limited regional mobility. It may therefore take a long time before a job is found, and there is a chance of staying unemployed or that the job found is outside the education programme's occupational domain or below the programme's level. Our empirical research takes into account such a lack of balance.

We look specifically at the differences between broad and narrow education programmes in relation to the following characteristics of the labour market positions of their graduates: whether graduates were still unemployed at the time of the survey and if they found a job, how long they searched for it, whether it was within the occupational domain of the education programme completed, and whether it was at the appropriate level. For graduates who found a job, we also investigate the differences between those with a narrow education and those with a broad one with regard to their wages, career prospects, and job satisfaction.

On the basis of the theoretical assumptions outlined above, we expect the following differences in labour market positions. Graduates from narrow education programmes are best prepared for the specific occupations targeted by the programme and are therefore preferred by employers providing jobs in these fields. If the supply of graduates sufficiently matches the demand for graduates in these specific occupational domains, graduates from narrow education programmes preparing for these domains will have a lower chance of being unemployed than graduates from related but broader programmes. After all, graduates from these broader education programmes are less attractive for these specific occupations. In this situation, graduates from narrow education programmes will also be more likely to find a job within the occupational domain and at the level of the programme completed. Because of their higher productivity within their occupational domain, wages will also be higher and, because of this, as well as the better match between their education and job, they will be more satisfied with their jobs and foresee better career opportunities. If demand in these specific occupational domains decreases, however, those who completed narrow education programmes will face unemployment more quickly than the more broadly educated, because the specific nature of their education prevents them from being able to change to other occupational domains. Once they have found a job outside the occupational domain of their education programme, the relatively unfavourable match will be likely to result in a job below the level of the education programme completed and their wages and satisfaction will be lower and their career opportunities worse than among those with a broader education who work outside their occupational domain.

In conclusion, since a mismatch between supply and demand in occupational submarkets is a rule rather than an exception and narrow education programmes provide a lower chance of occupational change, we expect graduates from narrow programmes, in general, to face unemployment more often than graduates from broad programmes and that the former take longer to find a job. Furthermore, graduates from narrow 
programmes who find a job in their domain will be paid better, will be more satisfied, will foresee better career opportunities, and will be more likely to have a job at their level than those from broader programmes who find a job in their domain. If graduates from narrow programmes need to resort to a job outside their occupational domain, however, we expect that such a job will pay less, will provide less satisfaction and worse career opportunities, and will be more likely to be below the level of their education programme than is the case among graduates from broader programmes working outside their occupational domain.

\section{Data}

Data set

The data set we use is the VE Monitor, an annual survey among VE graduates. This survey asks graduates about their labour market position approximately 18 months after graduation and about the match between the education programme completed and their jobs. Graduates are also asked their opinions on a variety of aspects of the completed programme. Our study aggregates the respondents from three years (2006-2008) to obtain a sufficiently large data set. This is important, particularly to differentiate optimally between the various education programmes. Our study focuses on Level 4 education programmes offered through the school-based learning route.

Level 4 is the highest level within upper-secondary VE. In 4 years, it prepares students for jobs at the middle management level. Education programmes are offered along two different learning routes: a school-based learning route, which is taken by approximately two-thirds of all students, and a work-based learning route (apprenticeship). Both routes lead to the same certification. To obtain a homogeneous data set of graduates in terms of labour market opportunities, we restrict ourselves to the school-based learning route, in which students gain practical experience during one or two days a week.

After graduation, students may move on to higher VE programmes provided by universities of applied science. Upper-secondary VE is preceded by pre-VE (4 years). After primary education, in addition to the aforementioned pre-VE programme, students have a choice of two types of general education: upper-secondary general education (5 years), which gives graduates access to universities of applied science, and pre-university education (6 years), which provides access to regular universities as well as universities of applied science. At the upper-secondary level, approximately two-thirds of all students took VE instead of general education during the sample period.

In total, the data set contains information on 10,187 respondents of Level 4 education programmes offered through the school-based learning route, clustered into 79 education programmes. To optimise the usefulness of further analyses, we require at least 15 workers for each education programme. This enables us to use 41 of the 79 education programmes, including six programmes in agriculture, 18 in technology, 10 in economics, four in health care, and three in behaviour and society. The 41 education programmes cover 10,091 respondents (99\% of all Level 4 respondents), which indicates that we exclude only very small programmes in our analyses. A total of 5621 respondents continued their education (55.7 \%) and 4086 entered the labour market, 3925 (96.1\%) of whom were working and 161 (3.9\%) of whom were unemployed at the time of the 
survey. The absence of certain variables for individual respondents could result in a lack of observations for various analyses.

\section{Key data of education programmes}

Table 1 specifies for each Level 4 VE (VE 4) education programme a number of characteristics for three categories of graduates that are important for our study: the population, which includes all graduates from an education programme; the labour force, which includes all those who found a job and those who are unemployed; and the employed (jobs), which includes only those who are working. The data in the table are grouped into five education sectors: agriculture, technology, economics, health care, and behaviour and society.

Across VE 4 as a whole, the percentage of graduates continuing their education is the highest $(55.7 \%)$, followed by the percentage moving into a job (38.9\%), three-quarters of whom found a job in the occupational domain for which their own or a related education programme is required (in Table 1 and further tables referred to as own domain)). Only a small percentage (5.4\%) is neither enrolled in an education programme nor in the labour market. The percentage of those moving on to further education varies greatly by programme. On average, this percentage is highest in the behaviour and society sector $(62.5 \%)$ and lowest in the health care sector $(40.7 \%)$. Variation within education sectors, however, can be great. This is particularly the case in the education sectors of technology, economics, and health care. Within technology, only $21.4 \%$ of the graduates from the shipping education programme move on to higher education, whereas in the building programme $65.3 \%$ do so. Within economics, only $37.7 \%$ graduates of the secretarial programme move on to higher education, versus no less than $81.8 \%$ in wholesale/distribution. Within health care, the percentages of graduates moving on to higher education are $27.8 \%$ for health care assistants and $68.2 \%$ for general and technical support services.

Compared to the other sectors, graduates with jobs in the economics and agriculture sectors most often find jobs outside their education programme's domain. The health care sector and the behaviour and society sector, however, have very high percentages of graduates who find jobs within the programme's occupational domain (88.8 and $82.2 \%$, respectively). Again, there are great differences between education programmes within a sector. The differences are greatest in the economics and health care sectors. Within economics, only $6.2 \%$ of business administration graduates who found a job were working in their programme's occupational domain, compared to $78 \%$ for automation specialists; within health care, $46.7 \%$ of the graduates from general and technical support services who found a job were working in their occupational domain, compared to no less than $94.3 \%$ for nursing and care graduates.

A relatively high rate of continuing their education or a relatively low rate of workers finding a job in the education programme's occupational domain may be an indicator of a broad programme. To complete a (mostly) higher follow-up education programme, one needs to have completed a sufficiently broad range of basic subjects with a certain theoretical depth, resulting in the acquired knowledge becoming more than what is strictly necessary to function in the occupational domain of the VE programme in question. Furthermore, a relatively high rate of graduates who find jobs outside the education 


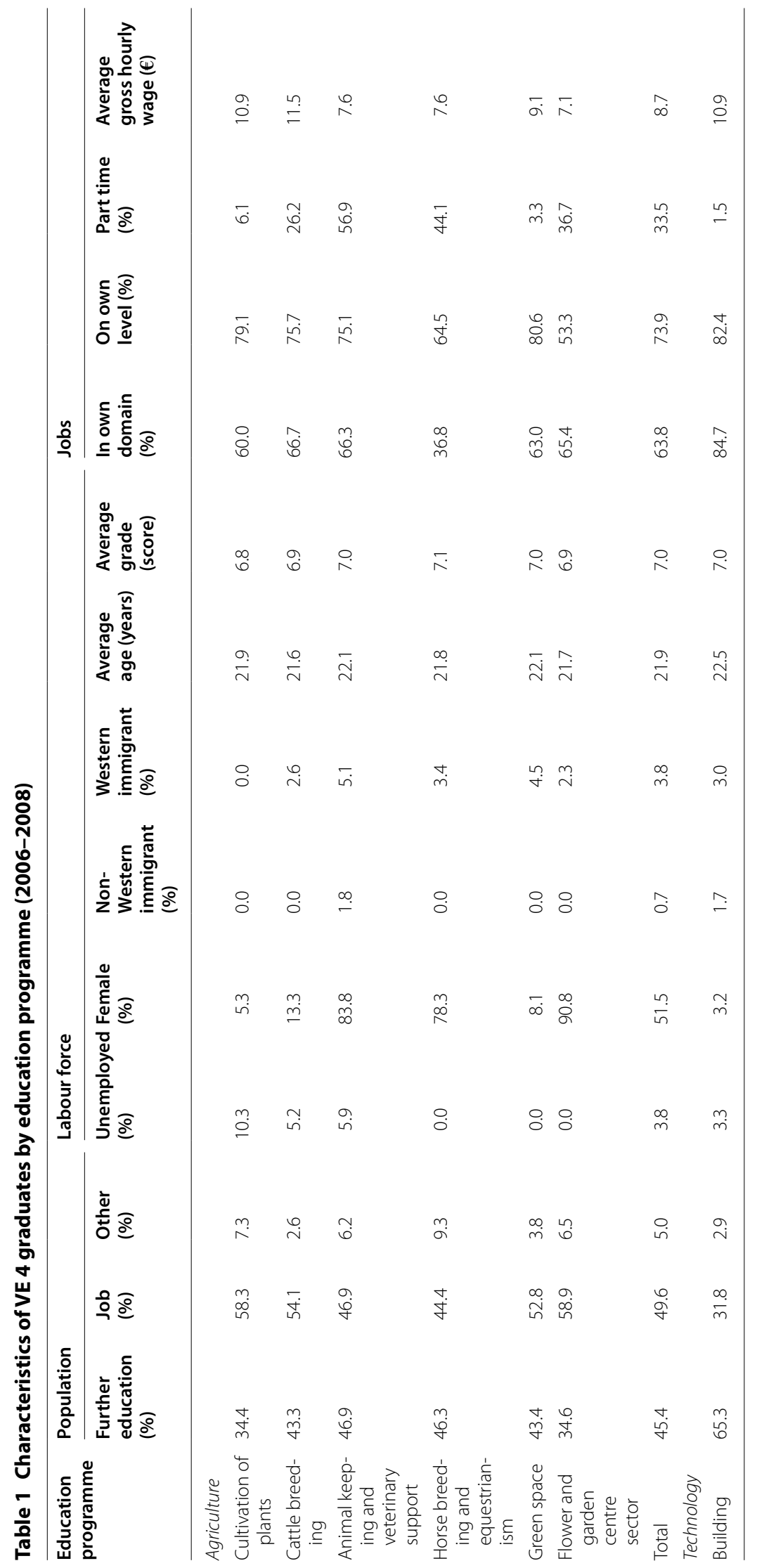




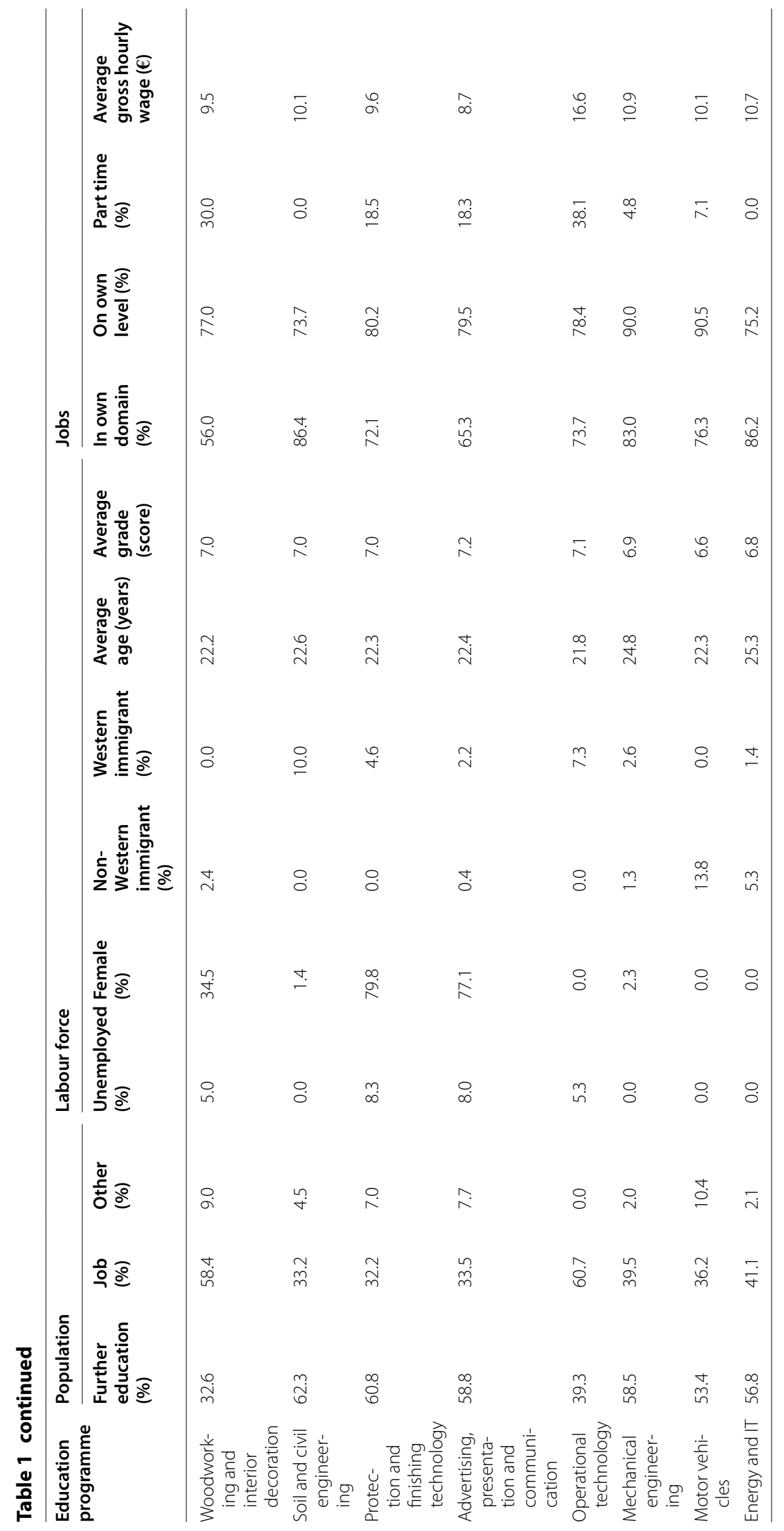




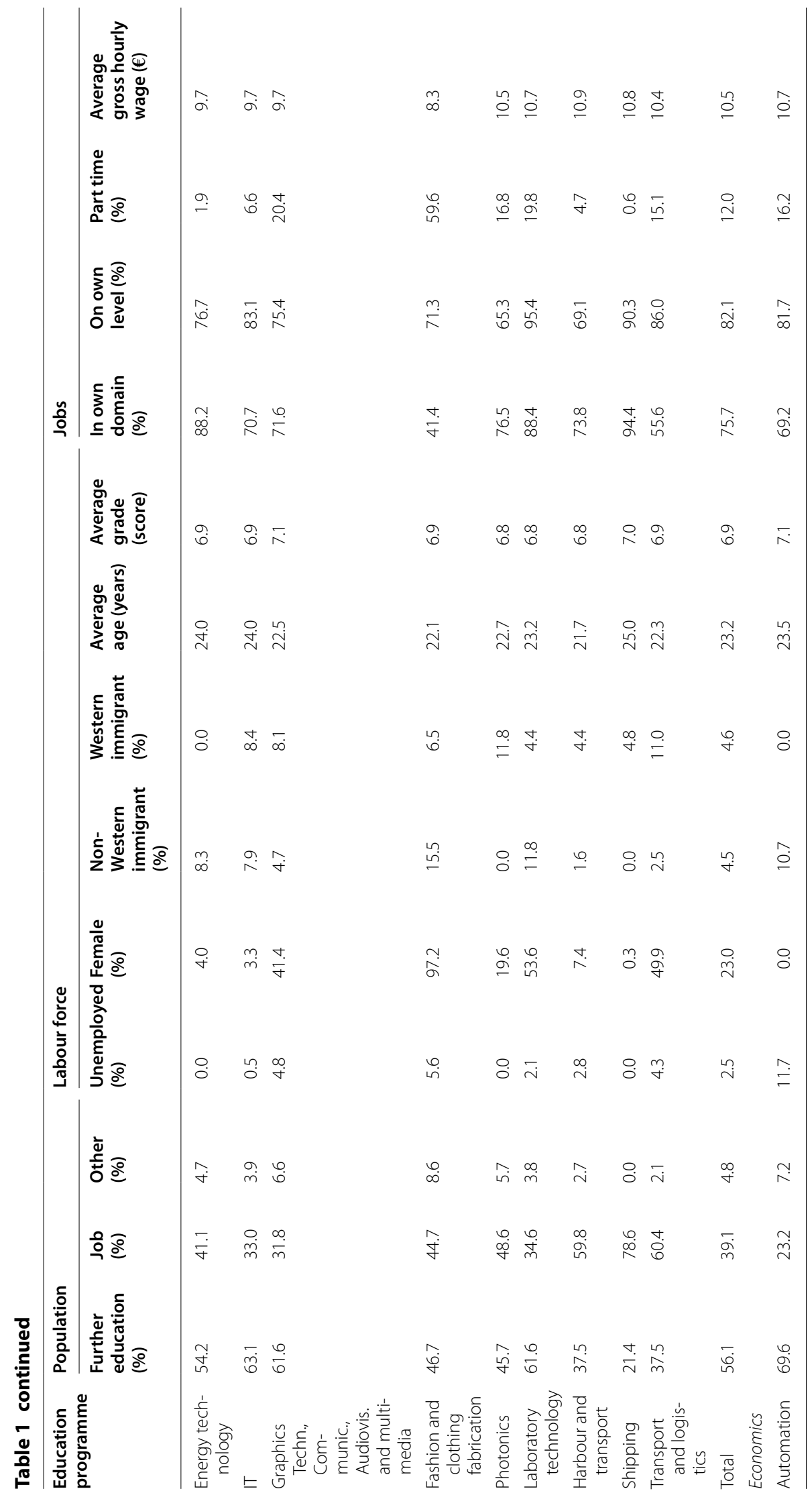




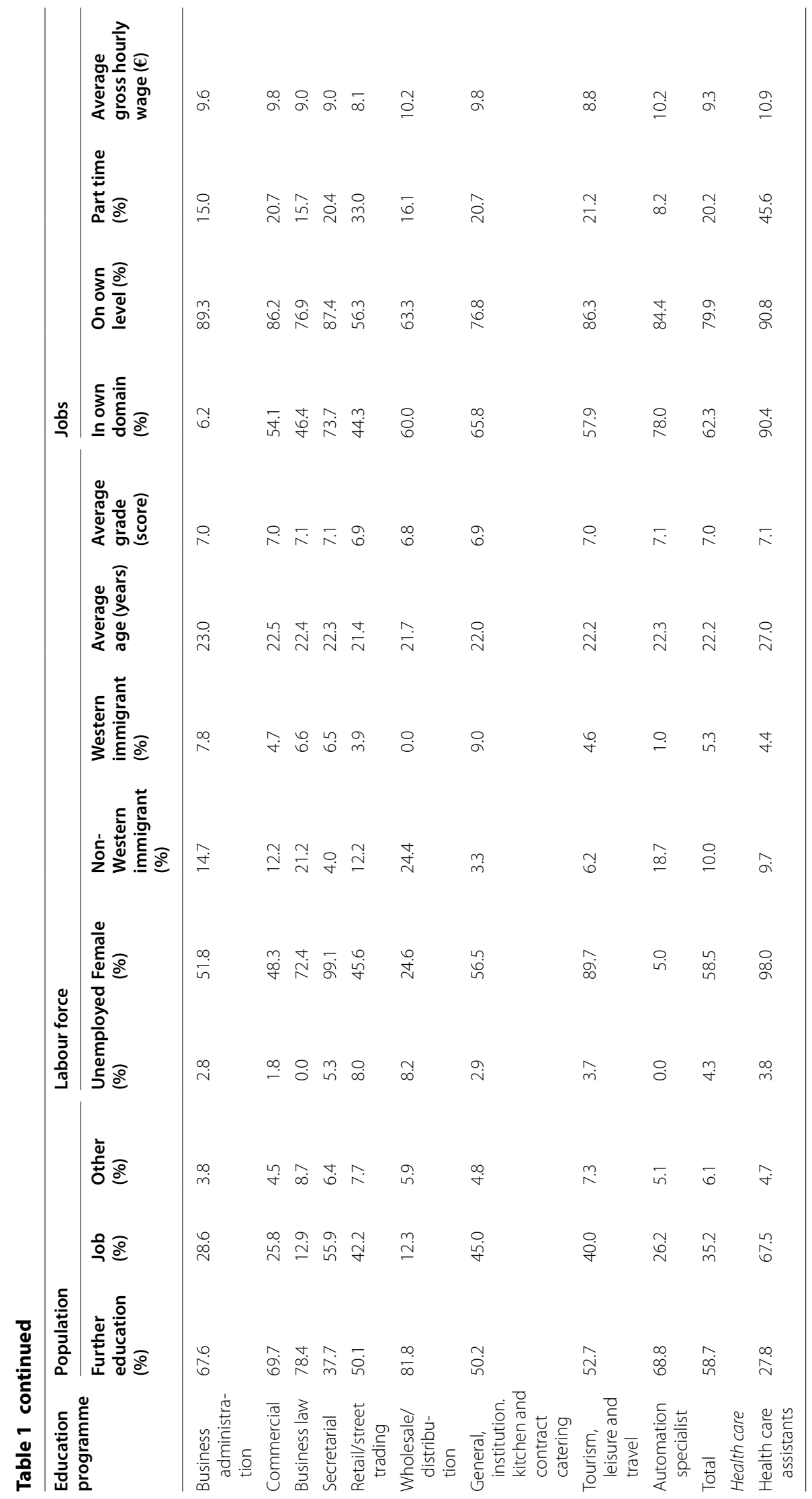




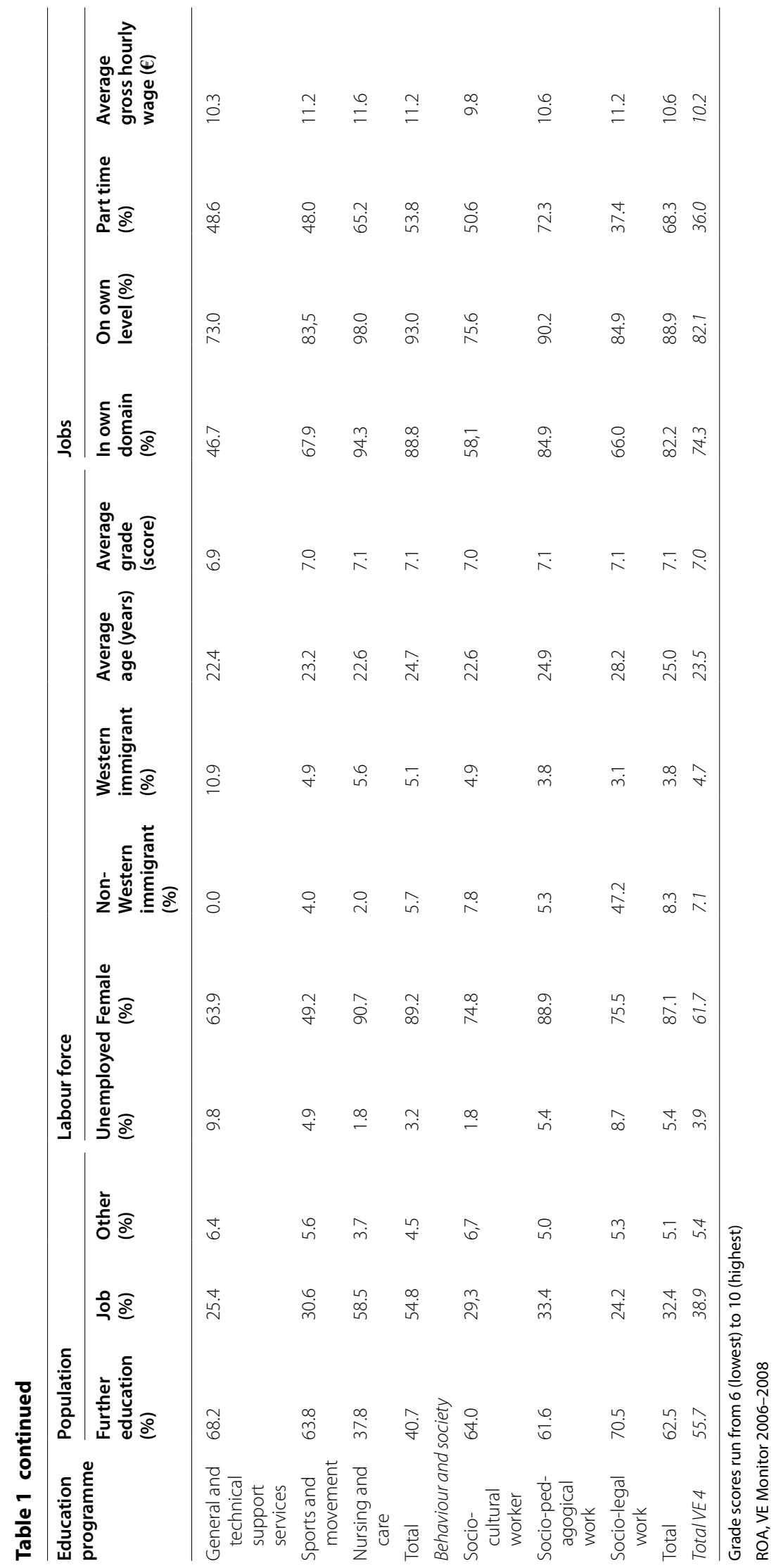


programme's occupational domain may point to a broad labour market perspective for the programme in question. Continuing education and finding a job outside the education programme's occupational domain may reinforce each other with regard to the broadness of the programme.

However, continuing education and finding a job outside one's occupational domain are also affected by factors that are not related to the broadness of the programme. Shifts in supply and demand in the labour market can have a major effect on both the rate of graduates moving on to further education and the percentage that need to find a job outside their occupational domain, regardless of the broadness of the programme. Furthermore, the percentage continuing their education as an indicator of the broadness of an education programme could be distorted if this percentage is limited by the absence of a higher-level programme that matches the VE programme in question. Therefore we do not proceed further with this idea. ${ }^{11}$

In addition to finding a job within one's occupational domain, a key indicator of graduates' labour market position is whether the job is at the level of the education programme completed (i.e. the job is on one's own level). For example, if an education programme is broad and therefore makes jobs accessible outside its occupational domain, it is important for these jobs to be at the programme's proper level. The percentage of graduates with a job at their level is very high, more than $82.1 \%$. The percentages of graduates with a job at their level in the education sectors of health care and behaviour and society are even higher, at 93.0 and $88.9 \%$, respectively. The percentage of graduates with a job at their level is lowest in the agricultural sector, $73.9 \%$.

Another key indicator of labour market position is unemployment. This is lowest among graduates from technical education programmes ( $2.5 \%$ of the labour force) and highest in the behaviour and society sector $(5.4 \%)$. The unemployment rates for individual education programmes vary greatly, ranging from $0 \%$ for 12 programmes to more than $10 \%$ for two programmes (the cultivation of plants and automation).

A final key indicator of labour market position is the gross hourly wage. The average wage of working graduates is lowest for those from agricultural programmes ( $€$ 8.7) and highest $(€ 11.2)$ for those from health care programmes. Although the wages of individual programmes do not deviate much from the average, $€ 10$, there are (very) high extreme values (operational technology, $€ 16.6$ ) and low extreme values (flower and garden centre sector, $€ 7.1)$.

Table 1 also includes a number of characteristics of graduates that serve as control variables for the estimations: the percentage of females, the percentages of non-Western and Western immigrants, average age, average final exam marks, and the percentage of part-time workers.

The majority of respondents in the labour force are female (61.7\%). They dominate the education sectors of health care and behaviour and society, with a share of about $90 \%$. Women constitute a minority (23\%), however, in the technology sector. In this sector, most educational programmes have no or only very few female graduates in the labour force. Educational programmes with a labour force that is about $100 \%$ female can, not

${ }^{11}$ Moreover, the statistical association between the shares of graduates moving on to further education and those who obtain a job outside their occupational domain is insignificant (the Pearson correlation coefficient is 0.22 , at a significance level of 0.17) 
surprisingly, be found in the sectors of health care (health care assistants), technology (fashion and clothing fabrication), and economics (secretarial).

The percentage of non-Western immigrants of the labour force $(7.1 \%)$ varies greatly by education programme. In the economics sector, $10.0 \%$ of the labour force belongs to this group, compared to only $0.7 \%$ in the agriculture sector. In many individual education programmes, there are hardly any or no non-Western immigrants among graduates in the labour force. However, the labour force for some education programmes consists of more than $20 \%$ non-Western immigrants, such as the economic programmes of business law (21.2 \%) and wholesale/distribution (24.4\%) and the behaviour and society sector programme of socio-legal work (47.2\%). The percentage of Western immigrants, however, is much smaller, at $4.7 \%$, and the percentages diverge less. Relatively large percentages of Western immigrants can be found in the technical education programmes of soil and civil engineering (10.0\%), photonics (11.8\%), and shipping $(11.0 \%)$ and in the health care programme of general and technical support services $(10.9 \%)$.

The average age at the time of the survey was 23.5 years. On average, this is a year older than one would expect on the basis of a nominal programme duration of two times four years. There may be various reasons for this, such as a change of course, repeating a year, failing the final exam, late entry, and interruption of the programme, for example, to work. The age variation below the average age is small, but large above it. The average age is lowest in the agricultural sector ( 21.9 years) and highest in the behaviour and society sector (25.0 years). The education programme with the lowest average age is the economics programme of retail/street trading (21.4 years), while in some programmes the average age is 25.0 years or older, such as the technical programmes of energy and IT (25.3 years) and shipping (25.0 years), the health care programme health care assistants (27.0), and the behaviour and society programme socio-legal work (28.2).

The average final examination grade for each programme in Table 1 takes into account the average grade scored across all subjects by the programme's graduates. The possible score per graduate ranges from 6 (pass) to 10 (excellent). The average score is 7.0 and it hardly differs between education sectors. The variation between individual education programmes is small, too. The figures generally range from 6.8 to 7.1 , with a low extreme of 6.6 (the technical programme of motor vehicles) and a high extreme of 7.2 (the technical programme of advertising presentation and communication).

On average, $36.0 \%$ of graduates work part-time. The variation in this percentage, however, is very large. The percentage of part-time workers is lowest among graduates from technical programmes $(12.0 \%)$ and highest among graduates in the behaviour and society sector $(68.3 \%)$. In the technical sector in particular, there are programmes for which part-time work is rare; nevertheless, there is a positive extreme, with a parttime percentage of almost $60 \%$ for the fashion and clothing fabrication programme (59.6\%). Similarly high figures occur in the health care sector, for the nursing and care programme $(65.2 \%)$, and in the behaviour and society sector for the socio-pedagogical work programme $(72.3 \%)$.

A control variable not specified in Table 1 is about the pursuit of any further education, and whether such education was completed (or rounded off with a partial certificate) or discontinued. 
We cannot control for heterogeneity of educational programmes by schools offering these programmes, because information about schools is lacking in the data set we use.

\section{Demarcation of narrow and broad education programmes} Introduction

An essential factor for the broadness of an education programme is the degree to which the knowledge and skills acquired through it are transferable to occupations other than that for which the programme prepares students. The greater this transferability, the broader the programme. In the most extreme case, the education programme is so generic that the knowledge and skills acquired can be applied in every occupation. At the other end of the broadness scale, a programme can be so specialised that the knowledge and skills can only be applied in a single occupation. In practice, however, there will always be a certain degree of transferability to other occupations.

The broadness of education programmes has been studied in various ways in the literature. Dolton and Vignoles (2002) look at upper-secondary education in the United Kingdom to determine the effect of the choice of a narrow or broad curriculum on later earnings in the labour market. Since this type of education is highly general, only a few broad disciplines can be distinguished. However, this does not yield a useful measure of the broadness of education programmes in countries such as the Netherlands and Germany, which have a system of secondary VE that is highly focussed on specific occupations.

A more suitable broadness measure for $\mathrm{VE}$-in line with the work of Warnken (1986) - is presented by Borghans and Heijke (1998). These authors determine the broadness of an education programme on the basis of the relative distribution of its working graduates across occupations in the labour market. The wider this distribution, the broader the programme. ${ }^{12}$ The distribution of working graduates is the result of how the labour market works. For our research, this measure yields a less favourable-tautological-definition of the broadness of a programme, because what we want to determine is exactly what the effect of this broadness is on labour market position.

A measure proposed by Lazear (2009) does not have this disadvantage. The author's skill-weights approach assumes that all skills (including knowledge) are of a general nature but that the combination in which they occur in an occupation is more or less specific. Geel and Backes-Gellner (2011) and Geel et al. (2011) apply this idea at the occupational level for VE graduates and Heijke and Meng (2011) do so for occupations at the higher education level. In this case, the more specific the occupation for which a programme prepares its students, the more the combination of skills in the occupation deviates from the required combinations in other occupations that are available in the labour market.

12 The measure used is the Gini-Hirschman index, which is based on the probability that two individuals who completed the same education programme find a job within the same occupation (Borghans and Heijke 1998). If one defines $f_{i j}$ as the share of workers with education $i$ in the employment of occupation $j$ and the total number of occupations as $m$, the education programme broadness measure $G H_{i}$ is

$$
G H_{i}=\left(1-\sum_{j} f_{i j}^{2}\right) \frac{m}{m-1}
$$

The index lies between zero and one and $G H_{i}$ equals zero if all workers with a particular educational background are in only one occupation. This measure therefore concerns a very narrow education programme. If $G H_{i}$ equals one, workers with that educational background are spread evenly across all occupations. This programme is therefore very broad. 
Among recent graduates, the acquired portfolio of skills will not fully match the portfolio required for proper performance in the occupation for which the students were trained. This is even less the case for those who have had to resort to a job outside this occupation. In our research, the broadness of an education programme should therefore preferably be determined on the basis of the acquired skill portfolio at the time of graduation and the perspective it offers on the labour market. Unfortunately, our data set does not provide information on the graduates' skill portfolios. Which means that we should adopt a different measure. ${ }^{13}$ To do so, we look at the extent to which graduates feel that the content of the education programme that they have completed has provided them with a broad perspective on the labour market. In concrete terms, we look at a measure that indicates whether the education programme completed matches the requirements of jobs inside one's occupational domain significantly better than an experienced match outside one's domain. If the match with jobs inside one's occupational domain compared to those outside it is indeed significantly better, the education programme is classified as narrow. In other cases, the education programme apparently provides no comparative advantage in jobs within its occupational domain and such programmes are classified as broad. In the following subsection, we provide some background information on this measure.

\section{Background of the demarcation criterion}

The VE Monitor survey asks graduates to rank the match between their education and their present job. We use this question to indicate the broadness or narrowness of an education programme. Graduates who completed a narrow, highly specialised education programme perceive themselves as well prepared for jobs within the programme's occupational domain and perceive their knowledge and skills to be of little use in jobs outside that domain. The difference experienced in graduates' matches between both types of occupational domains will therefore be large for a narrow programme. The knowledge acquired in a broad programme is, by definition, transferable to jobs outside the programme's domain. These graduates will therefore experience a better match outside the programme's domain than graduates from narrow education programmes. The knowledge and skills acquired in the education programme, however, will constitute less favourable preparation for jobs in the programme's domain than in the case of a narrow programme. The difference in graduates' matches between their education and a job in the programme's domain compared to matches experienced outside that domain will be small in the case of a broad programme-at least smaller than in the case of a narrow programme. The difference in the graduates' matches between the two domains can therefore be used as a measure of the distinction between narrow and broad education programmes.

The qualifications given by respondents to the match between the education that they completed and their jobs are subjective. One may wonder whether different types of respondents would be better able to assess the quality of the match, such as officials from

\footnotetext{
${ }^{13}$ Geel et al. (2011) developed-on the basis of occupational skill portfolios-a measure for the distance between occupations. This measure reflects the productivity shortage that workers experience if they have the skill portfolio concerned and switch to a different occupation than that for which they were trained. Since wages are related to productivity, this approach could be used to develop a measure of occupational specificity or the broadness of an education programme. For a discussion on wages as a measure of the match between the education programme completed and the job found, see Van Eijs and Heijke (2000). For an application of a wage measure specifically developed to measure the broadness of a VE programme, see Coenen et al. (2014). The wage measure of Geel et al., however, was derived from the labour market result of the education programme. As stated above, this renders the measure less useful as a broadness measure for research into the effects of programme broadness on the labour market position of graduates.
} 
schools and employers. Education officials would be quite capable of indicating the intentions of the education programme in relation to performance in jobs that are part of the occupational field. We think, however, that they would be less able to indicate the extent of the match with the requirements of actual jobs - less well, at any rate, than graduates could do for the jobs that they have. By analogy, employers should be able to indicate fairly well the requirements for certain jobs and their matching education programmes. Again, we doubt whether they would be better able than the young employees themselves to indicate to what extent the completed education programme is actually useful in the day-today performance requirements of the employees' specific jobs. Our approach is therefore quite defensible and we use the perceived match between one's education and one's job as a measure for the demarcation of narrow and broad education programmes.

\section{Application of the demarcation criterion}

The VE Monitor questionnaire asks the following question relating to the match between graduates' education and their job: 'How is the match between the education that you completed and your present position?' Respondents could choose from the options bad, moderate, sufficient, and good. For the matching criterion, we combine the two positive answers sufficient and good and set these off against the combined two opposite answers. Using a binomial logistic regression analysis of the graduates' answers on the matching question, we estimate for each education programme whether there is a significant difference between the graduates' match within their occupational domain and outside it. The explanatory variables are the graduate's education programme and whether this graduate works within the programme's occupational domain. A number of control variables are also taken into account.

This approach only allows us to see whether the match within the programme's occupational domain differs from that outside it. We cannot indicate how large this difference is. This means that we cannot indicate how broad an education programme is, but only whether it is narrow or broad.

The following equation is estimated:

$$
Y_{i o b}=\zeta+\theta_{o} d_{i o}+\lambda_{o} d_{i o} d_{i b}+\kappa \mathrm{X}_{i}+\mu_{t} d_{i t}+\pi_{i o b},
$$

where the explanatory variable $Y_{i o b}$ indicates the assessment of graduate $i$ who completed education programme $o$ and works in occupational domain $b$ of the match between the education programme completed and the current job. The variable is binary and takes the value one if the graduate indicates that the match between the education and the job is sufficient or good and zero in all other cases.

The variables $d_{i o}$ and $d_{i b}$ are dummy variables that equal one if the respondent completed education programme $o$ and works in the occupational domain for which their own or a related education programme is required, respectively, and zero otherwise. The term $X_{i}$ is a vector denoting the graduate's individual characteristics, included in the equation as control variables. The variable $d_{i t}$ is a dummy variable relating to the three survey years - 2006 to 2008-that equals one for the first and second years and zero for the last year. This variable represents changes over time that may affect the match between education and jobs, including shifts in the labour market. An error term $\pi_{i o b}$ with the usual properties is added to the equation.

The estimated coefficient $\lambda_{o}$ is the effect on the match if one works in the programme's occupational domain. We consider an education programme narrow if the estimated $\lambda_{o}$ 
is significantly positive. In that case, the match between one's education and one's job is better within the programme's domain than outside it. An education programme is classified as broad if the estimated $\lambda_{o}$ is not significantly different from zero or even negative. In that case, the match between the programme's domain does not differ from the match outside it and may even be worse.

Only respondents younger than 36 years are considered in the estimation. This prevents the results from being biased by the inclusion of older graduates, whose labour market position could be considered a less direct result of the VE programme completed 18 months before.

The estimations include control variables for the following: gender, age, age squared, status as a Western immigrant and as a non-Western immigrant, the final grade, parttime work status, a job at the programme's level, the pursuit of further education, and whether such education was completed (or rounded off with a partial certificate) or discontinued. These are all dummy variables, except age, which is measured in years. The interpretation of the dummy variables is obvious, except for the dummy for further education. It should be noted that this variable equals one if further education was completed or interrupted and equals zero if no further education was pursued.

The estimation of the perceived match between one's education and one's job and hence the division into narrow and broad education programmes thus derived may be biased because of non-observed characteristics and expectations among graduates, such as the ability of graduates and their motivation in the education programme. More able graduates, for example, may have managed to get more out of their education programme and hence experience a better match than their less able colleagues. Similarly, those who are more motivated by the broadness of an education programme may be more likely to experience a good match outside the programme's occupational domain than those who are more motivated by a programme's specialisation. The latter, on the other hand, may have more appreciation for a match if the job found is within the programme's occupational domain. To decrease this potential bias, we include as many control variables available in the data set as possible for the individual graduates. These include the average final grade across all subjects, as a proxy of the ability of the graduates. We also include variables that reveal the educational choices made after the vocational programme was completed. The same motivational factors could play a role here as those that played a role in the choice of a narrow or broad VE programme.

Applying the criterion based on the estimation of Eq. (1) results in the classification of education programmes into narrow and broad ones, as indicated by the check marks in Table 2 (for the underlying estimates, see Table 4 in "Appendix 1").

There appear to be 22 narrow programmes and 19 broad ones. In the case of the broad programmes, the match in the programme's domain never deviates significantly from the match outside it. For four broad programmes, however-operational technology, soil and civil engineering, laboratory technology, and shipping-the estimated coefficient indicating the difference in the match between the two types of occupational domains has an extreme absolute magnitude. All four appear to be technical education programmes for which the number of respondents working outside the programme's domain is very small, particularly because of the combination of the small number of working respondents and the relatively large number working within their occupational domain. One could therefore have doubts about classifying these education programmes 
Table 2 Classification of VE 4 education programmes as narrow or broad

\begin{tabular}{|c|c|c|}
\hline & $\begin{array}{l}\text { Narrow } \\
\text { programme }\end{array}$ & $\begin{array}{l}\text { Broad } \\
\text { programme }\end{array}$ \\
\hline \multicolumn{3}{|l|}{ Agriculture } \\
\hline Cultivation of plants & & $x$ \\
\hline Cattle breeding & $x$ & \\
\hline Animal keeping and veterinary support & $x$ & \\
\hline Horse breeding and equestrianism & $x$ & \\
\hline Green space & $x$ & \\
\hline Flower and garden centre sector & & $x$ \\
\hline \multicolumn{3}{|l|}{ Technology } \\
\hline Building & & $x$ \\
\hline Woodworking and interior decoration & $x$ & \\
\hline Soil and civil engineering & & $x$ \\
\hline Protection and finishing technology & & $x$ \\
\hline Advertising, presentation and communication & $x$ & \\
\hline Operational technology & & $x$ \\
\hline Mechanical engineering & $x$ & \\
\hline Motor vehicles & & $x$ \\
\hline Energy and IT & $x$ & \\
\hline Energy technology & & $x$ \\
\hline IT & & $x$ \\
\hline Graphic technology, communication, audiovisual and multimedia & & $x$ \\
\hline Fashion and clothing fabrication & $x$ & \\
\hline Photonics & & $x$ \\
\hline Laboratory technology & & $x$ \\
\hline Harbour and transport & & $x$ \\
\hline Shipping & & $x$ \\
\hline Transport and logistics & & $x$ \\
\hline \multicolumn{3}{|l|}{ Economics } \\
\hline Automation & $x$ & \\
\hline Business administration & $x$ & \\
\hline Commercial & $x$ & \\
\hline Business law & & $x$ \\
\hline Secretarial & $x$ & \\
\hline Retail/street trading & $x$ & \\
\hline Wholesale/distribution & $x$ & \\
\hline General, institutional kitchen, contract catering & $x$ & \\
\hline Tourism, leisure and travel & $x$ & \\
\hline Automation specialist & & $x$ \\
\hline \multicolumn{3}{|l|}{ Health care } \\
\hline Health care assistants & $x$ & \\
\hline General and technical support services & & $x$ \\
\hline Sports and movement & $x$ & \\
\hline Nursing and care & & $x$ \\
\hline \multicolumn{3}{|l|}{ Behaviour and society } \\
\hline Socio-cultural worker & $x$ & \\
\hline Socio-pedagogical work & $x$ & \\
\hline Socio-legal work & $x$ & \\
\hline
\end{tabular}


as broad. On the other hand, these programmes will have little effect on the analyses because of the small number of working graduates. ${ }^{14}$

According to the criterion used, only two of the six programmes in the agricultural education sector are broad. In the technology sector, however, about three-quarters (13 out of 18) of the programmes are broad. Of the 10 economics programmes, only two are broad. In health care, half of the programmes are broad, two out of four. Within the behaviour and society sector, however, none of the programmes are classified as broad.

The results for the technology sector are striking. In particular, in this sector, one would expect many narrow, specialist education programmes. However, our findings suggest that a great deal of technical knowledge can be transferred outside one's occupational domain or that the knowledge and skills acquired in technical education programmes have a strong general component. ${ }^{15}$ Unfortunately, we cannot check this finding with the available data set because the VE Monitor does not provide any direct information on the transferability of subject-specific knowledge. To analyse this aspect further, such information would have to be collected first, which is beyond the scope of this study. We therefore accept that the classification criterion based on the graduates' match between their education and job may not be a perfect measure and that it could be refined later, when more information becomes available regarding the transferability of skills.

\section{Labour market position of narrow versus broad education programmes} Labour market position indicators

We investigate the differences in labour market position between graduates from narrow education programmes and those from broad education programmes by carrying out regression analyses in which we relate various indicators of the labour market position with whether the programme completed is narrow or broad. Whether an education programme is narrow or broad is indicated here by means of a dummy variable that equals one if the programme is narrow and zero if the programme is broad. The regression coefficient of this dummy variable then shows the estimated effect of a narrow programme compared to that of a broad programme in the labour market position indicator.

The following labour market factors are considered: unemployment at the time of the survey, duration of the search for the first job, whether the job is at the level of the programme completed, whether it is within the programme's occupational domain, gross hourly wages, ${ }^{16}$ career perspectives, and job satisfaction. The VE Monitor does not measure these factors uniformly. The unemployment item involves a question about whether the respondent was unemployed at the time of the survey, a binary variable indicating whether the respondent was unemployed or not. Binary are also the variables based on the questions of whether the job was at the level of the programme completed and whether the job was within the occupational domain for which their own or a related education programme is required. For the questions concerning career prospects and job satisfaction and, the answers are graded on a five-point scale ranging from hardly to to a high extent or from very dissatisfied to very satisfied. In those cases, the grades indicated by the

\footnotetext{
${ }^{14}$ One solution would be to extend the data set with data from more recent years. However, these data would coincide with the current recession period, creating a split with the data from previous years.

15 What is clear is the fact that a large portion of VE graduate technicians work outside the industry and construction sectors, particularly in commercial services (e.g. De Grip and Marey 2006).

16 We use hourly wages rather than weekly or monthly wages to correct for working part-time.
} 
respondents were turned into a binary variable by grouping both positive qualifications together and setting these off against the three other, similarly grouped qualifications. With all these factors represented by binary variables, the effect of a narrow programme is estimated by means of a binomial logistic regression analysis. The two remaining factors are measured nominally. The duration of the search for the first job is measured in months and hourly wages are in euros. In these cases, an ordinary least squares (OLS) regression analysis is carried out. The population used in the analyses is not the same in all cases. The cases of unemployment and the duration of the search for the first job use graduates in the labour force and the remaining cases use only graduates with a job.

In addition to the dummy variable that indicates whether an education programme is narrow or broad, a number of control variables are used in the estimated regression analyses. To suppress a potential selectivity problem, we include all relevant controls available in the data set, including variables that proxy for the ability and motivation of the respondents. These proxy variables are the final grade, completion of a beta programme (technology, agriculture, health care), successful completion of further education, and the discontinuation of further education. Further controls are gender, age, age squared, non-Western and Western immigrant status, the year of the survey, working part-time, working in the programme's occupational domain, and working at the programme's level. Working in the programme's domain and working at the programme's level are included as controls in specified cases only. The other control variables recur in every analysis. For obvious reasons, the controls that characterize jobs do not play a role in the unemployment and duration of search analyses.

\section{Estimated effects of narrow versus broad education programmes on labour market position}

The estimation results for the seven labour market position indicators are shown in Table 3. This table shows the estimated effect of a narrow education programme for each indicator and, if included as control variables, the effects of working in the occupational domain of the education programme completed and at the programme's level. The logit estimates are represented by the log odds ratios. For the full estimation results, see Table 5 in "Appendix 2".

Although it does not take significantly longer for graduates from narrow education programmes to find their first job, their chances of being unemployed approximately 18 months after graduation appears to be significantly greater. This result is in line with our expectation that, if the employment prospects are less favourable, narrow education programmes provide fewer options to switch to occupations outside the programme's occupational domain.

It is striking that graduates from narrow education programmes have a significantly smaller chance of obtaining a job within the programme's occupational domain and a (weakly) significant smaller chance of obtaining a job at the programme's level. Both findings appear to be related. Taking into account whether respondents work within their domain this appears to have a positive effect on the chance of obtaining a job at the programme's level. Since the chances of working in one's occupational domain are lower for graduates from narrow education programmes, a negative effect on their chances of obtaining a job at the level of the programme results. This conclusion holds despite the insignificant negative direct effect of a narrow education on the job level in this case.

Gross hourly wages turn out to be significantly lower for graduates from narrow education programmes than for graduates from broad programmes. In this case, the 
Table 3 Labour market indicators of narrow versus broad VE programmes, logit/OLS estimates (controls: job in own domain and at own level)

\begin{tabular}{|c|c|c|c|}
\hline & $\begin{array}{l}\text { Narrow } \\
\text { programme }\end{array}$ & $\begin{array}{l}\text { Within } \\
\text { own domain }\end{array}$ & $\begin{array}{l}\text { At the } \\
\text { own level }\end{array}$ \\
\hline Unemployment (logit) & $0.586^{* * *}$ & & \\
\hline Duration of search (OLS) & 0.096 & & \\
\hline Job within own domain (logit, level as control) & $-0.459^{* * *}$ & & $2.146^{* * *}$ \\
\hline Job at own level (logit) & $-0.211^{*}$ & & \\
\hline Job at own level (logit, domain as control) & -0.015 & $2.143^{* * *}$ & \\
\hline Log gross hourly wage (OLS) & $-0.070^{* * *}$ & & \\
\hline $\begin{array}{l}\text { Log gross hourly wage (OLS, domain and level } \\
\text { as controls) }\end{array}$ & $-0.060^{* * *}$ & $0.060^{* * *}$ & $0.127^{* * *}$ \\
\hline $\begin{array}{l}\text { (Very) many career options (logit, domain and } \\
\text { level as controls) }\end{array}$ & $-0.548^{* * *}$ & 0.081 & $0.571^{* * *}$ \\
\hline $\begin{array}{l}\text { (Very) satisfied with job (logit, domain and level } \\
\text { as controls) }\end{array}$ & -0.089 & $0.422^{* * *}$ & $0.498^{* * *}$ \\
\hline
\end{tabular}

chances of finding a job within the programme's occupational domain and at the appropriate level appear to play a role. These chances have a significantly positive effect on wage levels. We find, however, that graduates from narrow education programmes have lower chances of finding a job in the programme's domain and consequently at the programme's level. Both aspects therefore have a negative effect on the hourly wage level of graduates from narrow education programmes.

We conclude from these results that graduates from narrow education programmes have an unfavourable labour market position. There is insufficient demand for these graduates, which makes it more difficult to find a job in their specific occupational domain and at the programme's level. Because of the limited options of resorting to other occupational domains, it takes longer for them to find a job and they lose jobs more easily. This weaker labour market position results in lower wages than those of graduates from broad programmes.

This conclusion is in line with our finding that graduates from narrow education programmes do experience significantly fewer career opportunities than graduates from broad programmes, particularly when a job is found below their level. Furthermore, this conclusion is also in line with our finding that, although having completed a narrow programme does not significantly affect graduates' job satisfaction, their lower chance of finding a job in the programme's domain and at its level will lead to job dissatisfaction among many of them.

\section{Summary and conclusions}

$\mathrm{VE}$ is subject to the eternal question of how broad the education programmes offered should be. According to theoretical lines of thought, in a narrow, specialist programme, the knowledge and skills taught aim to ensure that graduates experience a good match with occupational requirements once they find a job in the specific occupational domain targeted by the programme. If they find a job outside this occupational domain, however, the match will not be as good. In a broad education programme, the knowledge and skills acquired can be transferred to occupations outside the programme's specific occupational domain. This offers graduates the possibility of performing well in those occupations too. 
Broadly educated graduates therefore have wider labour market prospects than narrowly educated ones. At the same time, graduates from narrow education programmes will often be preferred in jobs within the programme's specific occupational domain. However, their labour market position is expected to be vulnerable in the case of insufficient employment within the occupational domains in which they have this preferred position.

In this study, we investigated how these theoretical expectations for narrow and broad education programmes turn out in practice during the transition phase from education to a job. For this purpose, we use data from three years of the VE Monitor surveys. These data concern the labour market position of graduates from VE 4 programmes in the school-based learning route 18 months after graduation.

In our study, the narrow education programmes were separated from the broad programmes on the basis of the criterion that, for narrow programmes, the match between one's education and one's job within the programme's occupational domain is better than in other occupational domains and that, for broad education programmes, this match for both types of occupational domains does not differ significantly. We found that the majority of the education programmes in the technology sector are broad and that, in the agriculture, economics, and behaviour and society sectors, most-and in the latter sector even all-of the programmes are narrow. In the health care sector, the situation turns out to be balanced. Because the classification criterion used may not be perfect, further investigation of the merits of these criterion would certainly be useful. Such a study could include research on the transferability of subject-specific knowledge and other competencies acquired in programmes to occupations outside the programme's occupational domain.

Our analyses of the labour market position of graduates from narrow education programmes compared to that of graduates from broad programmes show that the former have a less favourable labour market position. Graduates from narrow education programmes have a higher chance of unemployment and face more difficulties finding a job in their programme's occupational domain and at its level. They consequently have to resort more often to jobs outside their occupational domain and below their level. Once they find a job, they earn less than graduates from broad education programmes, particularly when the job is outside the domain of the education programme completed and below its level. Not surprisingly, graduates from narrow education programmes indicate that they have fewer career opportunities than graduates from broad programmes. On the other hand, they are not less satisfied with their job, unless this job is outside the programme's domain and below its level, which is unfortunately the case for many graduates of narrow programmes.

In particular, concerning our findings on the unfavourable labour market position of graduates from narrow education programmes, we want to be cautious about drawing the conclusion that narrow programmes should therefore be broadened. Such a change should be carefully considered, keeping in mind the potential productivity loss or higher adaptation costs that would ensue in the programme's occupational domain as a result. We think it would be better to focus on realising a shift in the influx of students from narrow to broad education programmes. This approach would create a better balance between the supply of graduates from narrow programmes and the available employment within their occupational domain. Fewer would then have to resort to jobs outside the programme's occupational domain, where they have no comparative advantage over graduates from other or broader programmes. This would guarantee the potential 
of graduates to perform optimally within their occupational domain - or at least better than graduates from related broader programmes could.

Shifting the student influx from narrow to broad programmes partly by offering broad variants of narrow programmes while maintaining the narrow, specialist variants could be highly allocation efficient. The narrow variants would then have to be offered on a smaller scale than before. This could avoid the productivity loss and adaptation costs that would ensue if employers can only recruit graduates from the broadened variants for jobs within the occupational domains of narrow education programmes.

Authors' contributions

The three authors cooperated closely as a team. JC and CM concentrated on carrying out the analyses. HH supervised the team and concentrated on drafting the manuscript. All authors read and approved the final manuscript.

\section{Author details}

${ }^{1}$ Top Institute for Evidence Based Education Research, Maastricht University, P.O. Box 616, 6200 Maastricht, MD, Netherlands. ${ }^{2}$ Department of Economics and Research Centre for Education and the Labour Market, Maastricht University, P.O. Box 616, 6200 Maastricht, MD, Netherlands. ${ }^{3}$ Research Centre for Education and the Labour Market, Maastricht University, P.O. Box 616, 6200 Maastricht, MD, Netherlands.

\section{Acknowledgements}

This paper is based on a study commissioned by the Dutch Centre for Expertise in Vocational Education and Training (ecbo): Johan Coenen, Hans Heijke, and Christoph Meng, 'Smal versus breed beroepsonderwijs. Arbeidsmarktpositie en curriculumkenmerken van smalle versus brede opleidingen', ecbo, 's-Hertogenbosch/Utrecht, Netherlands, December 2012. We are very grateful for the many helpful comments provided by the editor and referees of this journal.

Compliance with ethical guidelines

Competing interests

The authors declare that they have no competing interests.

\section{Appendix 1: Estimation of the demarcation between narrow and broad VE programmes}

See Table 4.

Table 4 Classification of VE 4 education programmes into narrow and broad, based on the difference in the education-job match between the programme's occupational domain and outside it, binomial logit

\begin{tabular}{|c|c|c|}
\hline & Narrow programme & Broad programme \\
\hline \multicolumn{3}{|l|}{ Agriculture } \\
\hline Cultivation of Plants & & -1.086 \\
\hline Cattle breeding & $2.052^{* *}$ & \\
\hline Animal keeping and veterinary support & $2.676^{* * *}$ & \\
\hline Horse breeding and equestrianism & $2.737^{* *}$ & \\
\hline Green space & $2.143^{* * *}$ & \\
\hline Flower and garden centre sector & & 1.170 \\
\hline \multicolumn{3}{|l|}{ Technology } \\
\hline Building & & 1.030 \\
\hline Woodworking and interior decoration & $2.625^{* *}$ & \\
\hline Soil and civil engineering & & -19.724 \\
\hline Protection and finishing technology & & 1.160 \\
\hline Advertising, presentation and communication & $2.041^{* * *}$ & \\
\hline Operational technology & & -19.472 \\
\hline Mechanical engineering & $1.189^{*}$ & \\
\hline Motor vehicles & & 0.403 \\
\hline Energy and IT & $2.091^{* *}$ & \\
\hline Energy technology & & 0.119 \\
\hline IT & & 1.161 \\
\hline
\end{tabular}


Table 4 continued

\begin{tabular}{|c|c|c|}
\hline & Narrow programme & Broad programme \\
\hline Graphic technology, communication, audiovisual and multimedia & & 0.901 \\
\hline Fashion and clothing fabrication & $2.526^{* * *}$ & \\
\hline Photonics & & 1.952 \\
\hline Laboratory technology & & 22.208 \\
\hline Harbour and transport & & 1.630 \\
\hline Shipping & & 23.259 \\
\hline Transport and logistics & & 0.064 \\
\hline \multicolumn{3}{|l|}{ Economics } \\
\hline Automation & $1.772^{* *}$ & \\
\hline Business administration & $1.343^{* * *}$ & \\
\hline Commercial & $1.241^{* * *}$ & \\
\hline Business law & & 0.524 \\
\hline Secretarial & $1.120^{* * *}$ & \\
\hline Retail/street trading & $1.885^{* * *}$ & \\
\hline Wholesale/distribution & $4.040^{* * *}$ & \\
\hline General, institutional kitchen, contract catering & $1.517^{* * *}$ & \\
\hline Tourism, leisure and travel & $1.520^{* * *}$ & \\
\hline Automation specialist & & 0.321 \\
\hline \multicolumn{3}{|l|}{ Health care } \\
\hline Health care assistants & $0.874^{*}$ & \\
\hline General and technical support services & & 0.866 \\
\hline Sports and movement & $2.904^{* * *}$ & \\
\hline Nursing and care & & 0.048 \\
\hline \multicolumn{3}{|l|}{ Behaviour and society } \\
\hline Socio-cultural worker & $3.264^{* * *}$ & \\
\hline Socio-pedagogical work & $1.090^{* * *}$ & \\
\hline Socio-legal work & $1.325^{*}$ & \\
\hline \multicolumn{3}{|l|}{ Personal characteristics } \\
\hline Female & 0.103 & \\
\hline Age & $-0.448^{* *}$ & \\
\hline Age2 & $0.008^{*}$ & \\
\hline Non-Western immigrant & $0.473^{* *}$ & \\
\hline Western immigrant & -0.283 & \\
\hline Final grade & 0.070 & \\
\hline \multicolumn{3}{|l|}{ Job characteristics } \\
\hline Part-time & 0.136 & \\
\hline At own level & $0.464^{* * *}$ & \\
\hline \multicolumn{3}{|l|}{ Further education } \\
\hline No further education & ref. & \\
\hline Interrupted & -0.054 & \\
\hline Completed or partial certificate & 0.490 & \\
\hline \multicolumn{3}{|l|}{ Year } \\
\hline 2006 & $-0.296^{* *}$ & \\
\hline 2007 & $-0.226^{* *}$ & \\
\hline 2008 & ref. & \\
\hline \multicolumn{3}{|l|}{ Constant $5.312^{* *}$} \\
\hline Nagelkerke $\mathrm{R}^{2}$ & 0.192 & \\
\hline-2 Log likelihood & 3462.364 & \\
\hline-2 Log likelihood & 3486 & \\
\hline
\end{tabular}

The superscripts ***,**, and * indicate significance at the 1,5 , and $10 \%$ levels, respectively. The estimates are represented by the log odds ratios. Sector dummies are not shown 
Coenen et al. Empirical Res Voc Ed Train (2015) 7:9

Page 29 of 31

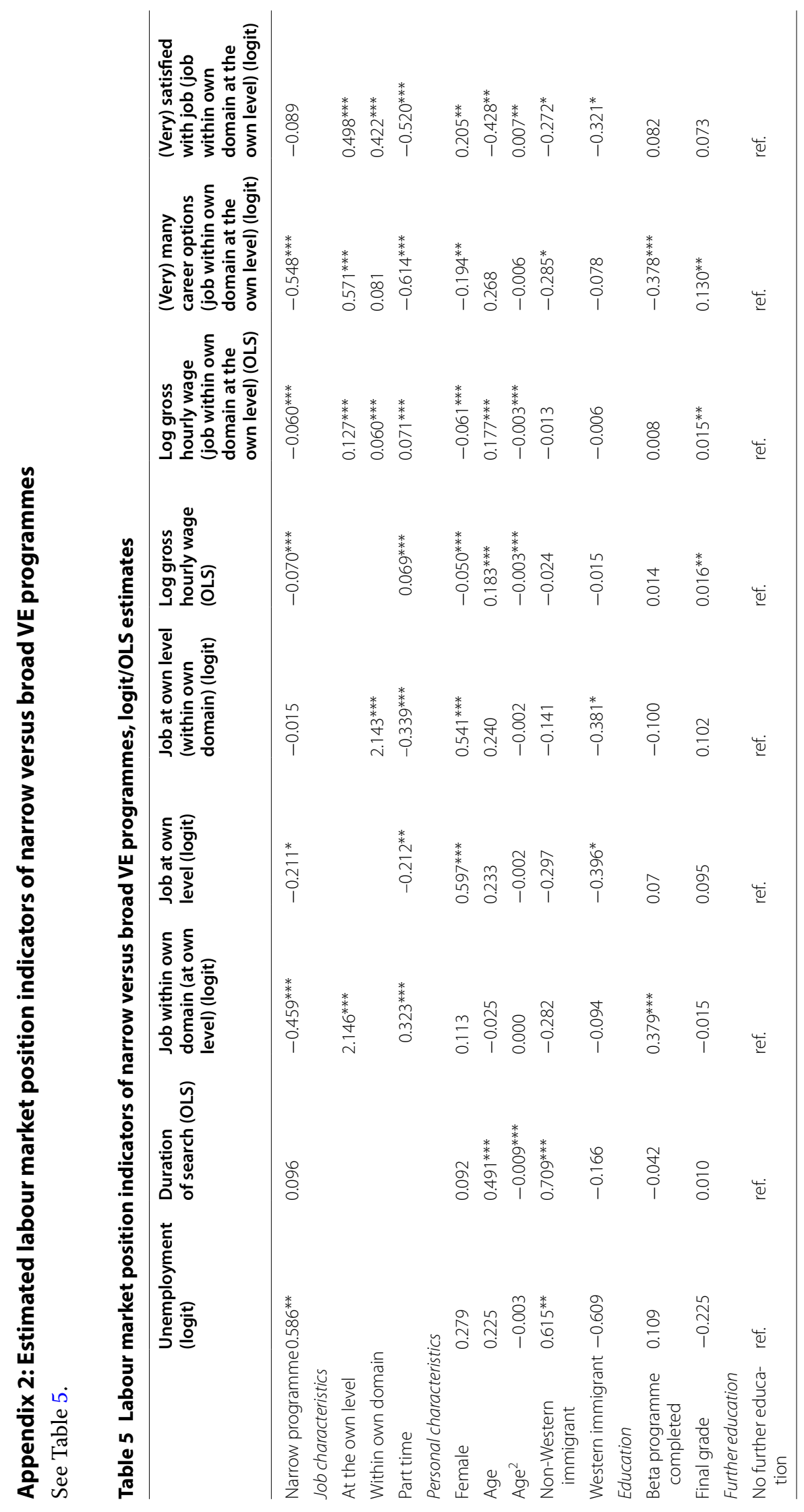




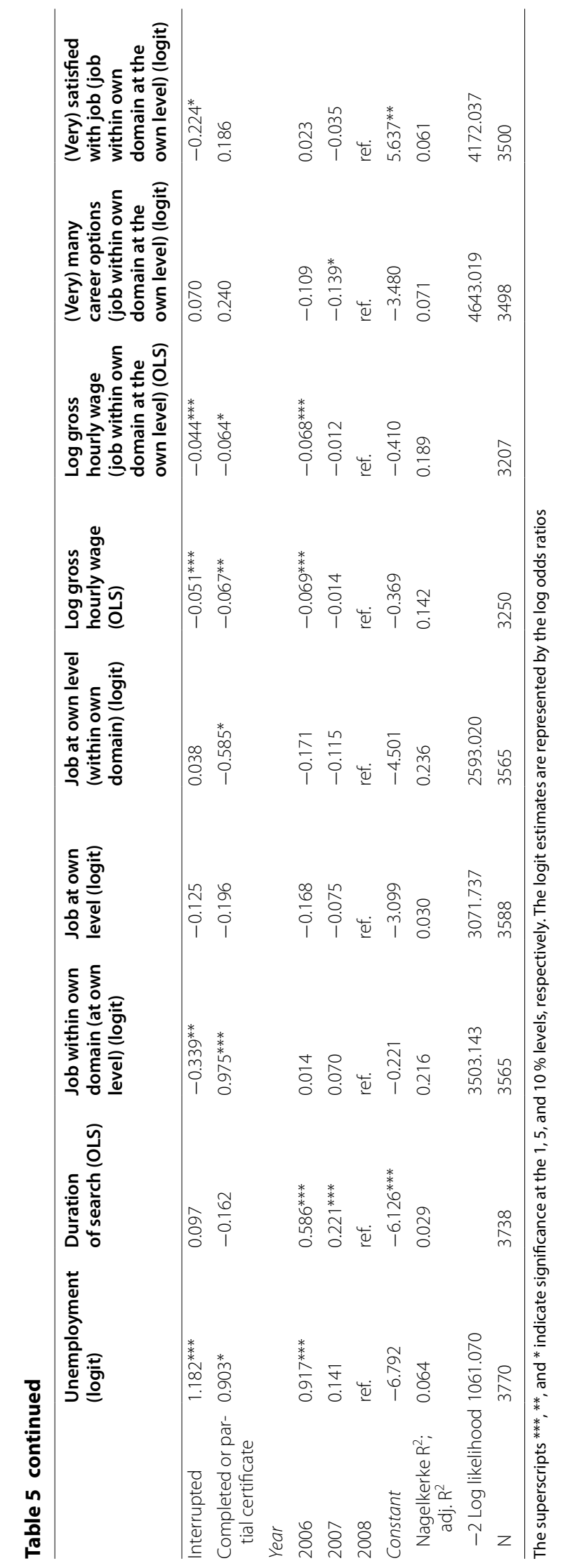


Received: 6 October 2014 Accepted: 4 August 2015

Published online: 26 August 2015

\section{References}

Acemoglu D, Pischke J (1998) Why do firms train? Theory and evidence. Q J Econ 113(1):79-119

Becker G (1962) Investment in human capital: a theoretical analysis. J Polit Econ 70(supplement):9-49

Borghans L, De Grip A (1999) Smal en breed opleiden: productiviteit versus flexibiliteit. In: Gids voor de Opleidingspraktijk, vol 28. Samsom, Deventer, pp 1-33

Borghans L, Heijke H (1998) Flexibility and structure of the Dutch labour market. In: Heijke H, Borghans L (eds) Towards a transparent labour market for educational decisions. Ashgate, Aldershot, pp 119-150

Borghans L, Heijke H (2004) Promoting the macro-efficiency of vocational education? In: Nijhof WJ, van Esch W (eds) Unraveling policy, power, process and performance: the formative evaluation of the Dutch Adult and Vocational Education Act. CINOP, 's-Hertogenbosch, pp 79-98

Carrington WJ (1993) Wage losses for displaced workers: Is it really the firm that matters? J Hum Resour 28(3):435-462

Coenen J, Heijke H, Meng C (2014) Narrow versus broad vocational education: Labour market position and curriculum characteristics of specialised versus less specialised vocational education programmes in the Netherlands. ROATR-2014/4. Research Centre for Education and the Labour Market, Maastricht

De Grip A, Marey P (2006) Het werkveld van bètatechnici. In: De Grip A, Marey P (eds) Technotopics, essays over onderwijs en arbeidsmarkt voor bètatechnici. Platform Bèta Techniek, The Hague, pp 47-54

Dolton P, Vignoles A (2002) Is a broader curriculum better? Econ Educ Rev 21:415-429

Dothan U, Williams J (1981) Education as an option. J Bus 54(1):117-139

Dupuy A (2004) Assignment and substitution in the labor market. ROA Dissertation Series No. 4. Research Centre for Education and the Labour Market, Maastricht

Euwals R, Winkelmann R (2001) Why do firms train? Empirical evidence on the first labour market outcomes of graduated apprentices. Discussion Paper 319. IZA, Bonn

Franz W, Soskice D (1995) The German apprenticeship system. In: Buttler F, Franz W, Shettkat R, Soskice D (eds) Institutional frameworks and labor market performance. Routledge, London, pp 208-234

Geel R, Backes-Gellner U (2011) Occupational mobility within and between skill clusters: an empirical analysis based on the skill-weight approach. Empir Res Vocat Educ Train 3(1):21-38

Geel R, Mure J, Backes-Gellner U (2011) Specificity of occupational training and occupational mobility: an empirical study based on Lazear's skill-weights approach. Educ Econ 19(5):519-535

Hartog J (1992) Capabilities, allocation and earnings. Kluwer Academic Publishers, Boston

Heijke H, Borghans L (1998) Investing in education. In: Heijke H, Borghans L (eds) Towards a transparent labour market for educational decisions. Ashgate, Aldershot, pp 1-18

Heijke H, Meng C (2011) The effects of higher education programme characteristics on the allocation and performance of the graduates. Educ Econ 19(1):1-27

Jovanovic B (1979) Job matching and the theory of turnover. J Polit Econ 87:1246-1260

Katz E, Ziderman A (1990) Investment in general training: The role of information and labour mobility. Econ J 100(403):1147-1158

Lazear EP (2009) Firm-specific human capital: a skill-weights approach. J Polit Econ 117(5):914-939

Müller B, Schweri J (2012) The returns to occupation-specific human capital—evidence from mobility after training. Leading House Working Paper No. 81. Zürich University/Bern University

Neil D (1995) Industry-specific human capital: evidence from displaced workers. J Labor Econ 13(4):653-677

Nijhof WJ (1998) Qualifying for the future. In: Nijhof WJ, Streumer JN (eds) Key qualifications in work and education. Kluwer Academic, Boston, pp 19-38

Pfeifer H, Schönfeld G, Wenzelmann F (2011) How large is the firm-specific component of German apprenticeship training? Empir Res Vocat Educ Train 3(2):85-104

Research Centre for Education and the Labour Market (2007) De arbeidsmarkt naar opleiding en beroep tot 2012. ROA-R2007/4. Research Centre for Education and the Labour Market, Maastricht

Research Centre for Education and the Labour Market (2010) Schoolverlaters tussen onderwijs en arbeidsmarkt 2009. ROA-R-2010/7. Research Centre for Education and the Labour Market, Maastricht

Sattinger M (1975) Comparative advantage and the distribution of earnings. Econometrica 43(3):455-468

Sattinger M (1993) Assignment models of the distribution of earnings. J Econ Lit 31:831-880

Smits W (2005) The quality of apprenticeship training - the conflicting interests of firms and apprentices ROA Dissertation Series No 5. Research Centre for Education and the Labour Market, Maastricht

Statistics Netherlands (2011) Statistical yearbook 2011. Statistics Netherlands, The Hague

Stevens M (1994) A theoretical model of on-the-job training with imperfect competition. Oxford Econ Pap 46(4):537-562

Teulings C (1995) The wage distribution in a model of the assignment of skills to jobs. J Polit Econ 103(2):280-315

Tinbergen $J$ (1956) On the theory of income distribution. Rev World Econ 77(2):155-175

Van Eijs P, Heijke H (2000) Mismatch between occupation and education and the costs and benefits of job-related training. In: Heijke H, Muysken J (eds) Education and training in a knowledge-based economy. Macmillan, London, pp 159-189

Van Hoof JJ, Dronkers J (1980) Onderwijs en arbeidsmarkt: Een verkenning van de relatie tussen onderwijs, arbeidsmarkt en arbeidssysteem. Van Loghum Slaterus, Deventer

Warnken J (1986) Zur Entwicklung der'Internen'Anpassungsfähigkeit der Berufe bis zum Jahre 2000. MittAB 19:119-133

Weinberg BA (2001) Long-term wage fluctuations with industry-specific human capital. J Labor Econ 19(1):231-264 